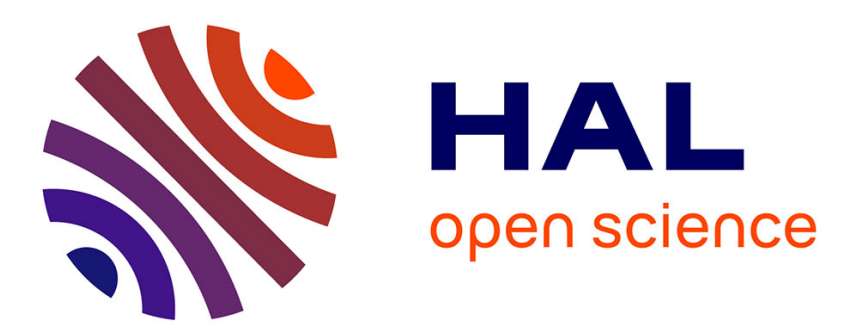

\title{
Synthetic Studies on Hemicalide: Development of a Convergent Approach toward the C1-C25 Fragment
}

Geoffroy Sorin, Etienne Fleury, Christine Tran, Elise Prost, Nicolas Molinier, François Sautel, Georges Massiot, Simon Specklin, Christophe Meyer, Janine Cossy, et al.

\section{To cite this version:}

Geoffroy Sorin, Etienne Fleury, Christine Tran, Elise Prost, Nicolas Molinier, et al.. Synthetic Studies on Hemicalide: Development of a Convergent Approach toward the C1-C25 Fragment. Organic Letters, 2013, 15 (18), pp.4734-4737. 10.1021/ol402077e . hal-02370568

\section{HAL Id: hal-02370568 https://hal.science/hal-02370568}

Submitted on 14 Oct 2021

HAL is a multi-disciplinary open access archive for the deposit and dissemination of scientific research documents, whether they are published or not. The documents may come from teaching and research institutions in France or abroad, or from public or private research centers.
L'archive ouverte pluridisciplinaire HAL, est destinée au dépôt et à la diffusion de documents scientifiques de niveau recherche, publiés ou non, émanant des établissements d'enseignement et de recherche français ou étrangers, des laboratoires publics ou privés. 


\title{
Synthetic Studies on Hemicalide: Development of a Convergent Approach toward the $\mathrm{C} 1-\mathrm{C} 25$ Fragment
}

\author{
Geoffroy Sorin, ${ }^{\dagger}$ Etienne Fleury, ${ }^{\dagger}$ Christine Tran, ${ }^{\dagger}$ Elise Prost, ${ }^{\dagger}$ Nicolas Molinier, ${ }^{\ddagger}$ \\ François Sautel, ${ }^{\ddagger}$ Georges Massiot, ${ }^{\ddagger}$ Simon Specklin, ${ }^{\S}$ Christophe Meyer, ${ }^{\S}$ \\ Janine Cossy, ${ }^{\S}$ Marie-Isabelle Lannou, ${ }^{\dagger}$ and Janick Ardisson ${ }^{\star, \dagger}$ \\ Faculté de Pharmacie, Université Paris Descartes, CNRS UMR 8638, 4 avenue de \\ l'observatoire, 75270 Paris Cedex 06, France, CNRS-Pierre Fabre USR 3388, \\ Centre de Recherche \& Développement Pierre Fabre, 3 avenue Hubert Curien, 31035 \\ Toulouse Cedex 01, France, and Laboratoire de Chimie Organique, ESPCI ParisTech, \\ CNRS UMR 7084, 10 rue Vauquelin, 75231 Paris Cedex 05, France
}

janick.ardisson@parisdescartes.fr

\section{ABSTRACT}

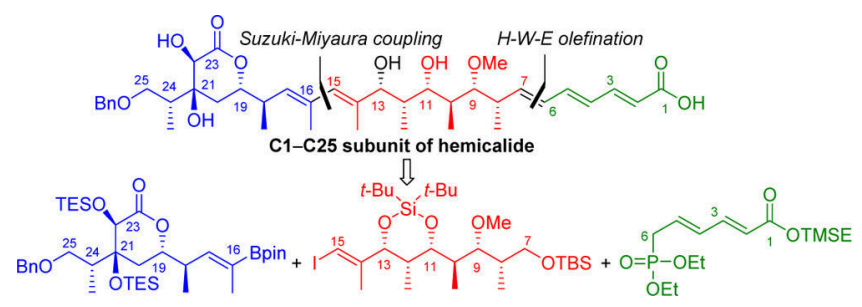

Synthetic studies on hemicalide, a recently isolated marine natural product displaying highly potent antiproliferative activity and a unique mode of action, have highlighted a reliable Horner-Wadsworth-Emmons olefination to create the C6-C7 alkene and a remarkable efficient SuzukiMiyaura coupling to form the $\mathrm{C} 15-\mathrm{C} 16$ bond, resulting in the development of a convergent approach toward the $\mathrm{C} 1-\mathrm{C} 25$ fragment.

The identification of structurally new and highly potent bioactive lead compounds from marine sources has become an active area of research. ${ }^{1}$ Although it could offer considerable promise, investigations into the deep sea environment remain rather scarce. Recently, researchers of the CNRS-Pierre Fabre Laboratories joint unit in association with the Institut de Recherche pour le Développement (IRD) collected the marine sponge Hemimycale sp. in deep water around the Torres Islands (Vanuatu). Bioassay-guided fractionation led to the isolation of the new complex polyketide hemicalide $\mathbf{1}$ as a potent mitotic blocker which displays high antiproliferative potency against a panel of human cancer cell lines at subnanomolar concentrations. ${ }^{2}$ Additionally, the initially

\footnotetext{
†Université Paris Descartes.

CNRS-Pierre Fabre USR 3388.

${ }^{\S}$ ESPCI ParisTech.

(1) For a recent review on marine natural products, see: Blunt, J. W.; Copp, B. R.; Keyzers, R. A.; Munro, M. H. G.; Prinsep, M. R. Nat. Prod. Rep. 2013, 30, 237-323. 2011.

2) Carletti, I.; Massiot, G.; Debitus, C. WO 2011/051380A1 patent,
}

conducted immuno-cytochemistry studies indicated that this compound acted by a unique mechanism that involved the destabilization of the $\alpha / \beta$ microtubule network. The planar structure of hemicalide $\mathbf{1}$, which was assigned by extensive NMR studies, indicated a 46 carbon atom backbone comprised of 21 stereocenters and several remarkable structural elements: a conjugated trienic acid (C1-C7), a six-carbon polypropionate motif $(\mathrm{C} 8-\mathrm{C} 13)$, a conjugated diene (C14-C17), and $\alpha, \beta$-dihydroxy (C19-C23) as well as $\alpha$-hydroxy (C37-C41) $\delta$-lactones. Due to the extremely limited supply of hemicalide (less than $1 \mathrm{mg}$ was isolated), neither derivatization nor degradation experiments could be carried out and the configuration of the stereocenters was not assigned. Intrigued by the architectural complexity and promising bioactivity of hemicalide, we embarked on determining the relative configuration and the total synthesis of this natural product. In previous work, a careful comparison of the NMR data of appropriate diastereomeric model compounds with those of hemicalide allowed us to assign the relative configuration of the $\mathrm{C} 8-$ C13 subunit $^{3}$ as well as the $\alpha, \beta$-dihydroxy $\delta$-lactone 
(C19-C23) bearing adjacent methyl-substituted stereocenters (C18 and C24) (Figure 1). ${ }^{4,5}$ Herein, we report the results of our ongoing synthetic studies on hemicalide which have enabled us to discover appropriate coupling reactions to assemble three key subunits of the natural product of value for a convergent approach toward the C1-C25 fragment.

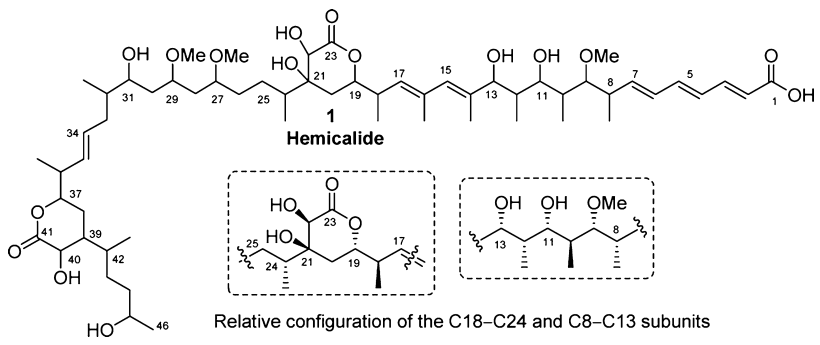

Figure 1. Structure of hemicalide 1 and relative configurations of the $\mathrm{C} 8-\mathrm{C} 13$ and $\mathrm{C} 18-\mathrm{C} 24$ subunits.

With the goal of devising a convergent strategy toward the $\mathrm{C} 1-\mathrm{C} 25$ subunit of hemicalide, two key disconnection points were identified. As illustrated for one putative diastereomer $\mathbf{A}$, formation of the $\mathrm{C} 15-\mathrm{C} 16$ bond was envisaged by a Suzuki-Miyaura coupling between a trisubstituted alkenylboronate at $\mathrm{C} 16$ and a trisubstituted alkenyl iodide at $\mathrm{C} 15$ whereas formation of the $\mathrm{C} 6-\mathrm{C} 7$ olefin would be accomplished by a Horner-Wadsworth-Emmons (H-W-E) olefination. Therefore, the synthesis of the $\mathrm{C} 1-\mathrm{C} 25$ fragment of hemicalide was planned from three key subunits: phosphonate $\mathbf{D}$ incoporating a $(E, E)$-dienoate $(\mathrm{C} 1-\mathrm{C} 6)$, alkenyl iodide $\mathbf{C}(\mathbf{C} 7-\mathrm{C} 15)$ containing six stereocenters, and alkenyl boronate $\mathbf{B}$ comprising the $\alpha, \beta$-dihydroxy $\delta$-lactone moiety (C16-C25) (Scheme 1).

Scheme 1. Retrosynthetic Analysis of the C1-C25 Subunit A

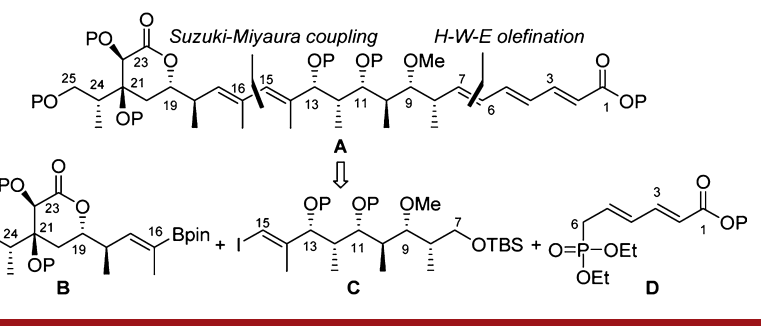

Synthesis of the C16-C25 subunit B was investigated first. In our previously described synthetic approach to a model compound for the $\mathrm{C} 17-\mathrm{C} 25$ subunit of hemicalide

(3) Fleury, E.; Lannou, M.-I.; Bistri, O.; Sautel, F.; Massiot, G.; Pancrazi, A.; Ardisson, J. J. Org. Chem. 2009, 74, 7034-7045.

(4) Fleury, E.; Sorin, G.; Prost, E.; Pancrazi, A.; Sautel, F.; Massiot, G.; Lannou, M.-I.; Ardisson, J. J. Org. Chem. 2013, 78, 855-864.

(5) It is worth noting that the relative configuration of the $\mathrm{C} 8-\mathrm{C} 13$ subunit of hemicalide was later confirmed by Goodman and Smith using Gauge-Inducing-Atomic-Orbital (GIAO) NMR calculations: Smith, S. G.; Goodman, J. M. J. Am. Chem. Soc. 2010, 132, 12946-12959.
(5), the cis-1,2-diol at C21,C22 was installed by dihydroxylation of an $\alpha, \beta$-unsaturated $\delta$-lactone $\mathbf{3}$ which in turn arose from an intramolecular $\mathrm{H}-\mathrm{W}-\mathrm{E}$ olefination of the keto-phosphonate 2. ${ }^{4}$ Despite considerable optimization, $\beta$-elimination leading to enone $\mathbf{4}$ unavoidably took place as a side reaction $(17 \%)$. Another matter of concern was that aldehyde $\mathbf{6}$, generated from compound 5, could not be successfully engaged in a dibromomethylenation or a Wittig-type reaction and underwent decomposition instead (Scheme 2).

Scheme 2. Previous Synthesis of $\delta$-Lactone Model 5
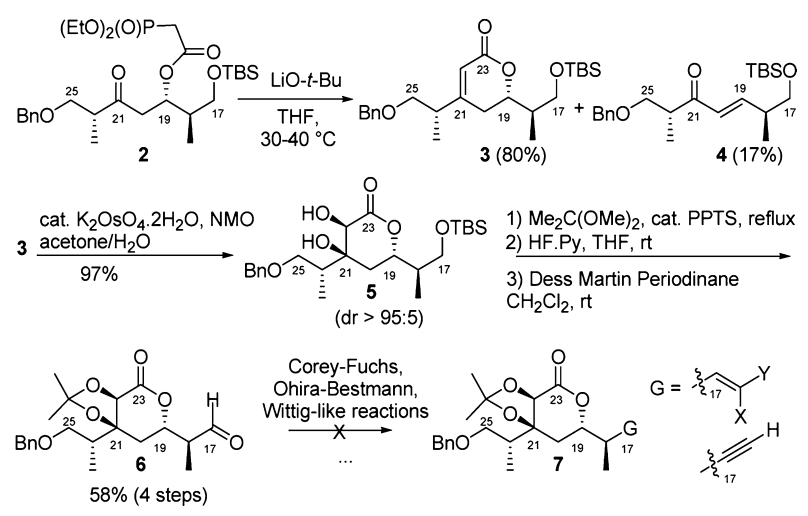

Due to the difficulties encountered in the carbon chain extension of aldehyde 6 at C17, a new strategy was devised wherein an appropriate precursor of the $\mathrm{C} 16-\mathrm{C} 17$ trisubstituted $(E)$-alkene was present before construction of the lactone core. Thus, aldehyde $(R)-\mathbf{8}$ possessing a trisusbtituted alkenyl bromide, readily available from an $(S)$-Roche ester, ${ }^{6}$ was engaged in a Dias allylation with the chiral allylsilane $(S)-9$ (prepared from $(R)$-Roche ester). ${ }^{4}$ The reaction proceeded with high diastereoselectivity ( $\mathrm{dr}>95: 5)$, and the resulting homoallylic alcohol 10 was isolated in $62 \%$ yield as a $85: 15$ mixture of corresponding $(E)$ and $(Z)$ diastereomers. After acylation of the hydroxy group with bromoacetyl bromide, the presence of the trisubstituted vinylic bromide allowed for the chemoselective ozonolysis of the exo-methylene group ${ }^{7}$ to provide ketone 11 albeit in moderate yield (50\%). Interestingly, as an alternative approach, an aldol reaction involving methyl ketone $\mathbf{1 2}$ as a partner (prepared from ( $R$-Roche ester) was examined. ${ }^{8}$ Addition of the titanium enolate derived from $\mathbf{1 2}$ to aldehyde $(R)-\mathbf{8}$ proceeded with satisfying diastereoselectivity $(\mathrm{dr}=90: 10)$ and led to compound $11(73 \%)$ after acylation of the hydroxy group at C19 with bromoacetyl bromide, thereby avoiding the

(6) In our hands, the alcohol precursor of aldehyde $(R)-\mathbf{8}$ was obtained as an inseparable mixture of the two corresponding $(E)$ and (Z) olefins $(\mathrm{dr}=85: 15)$. (a) Cho, C.-G.; Kim, W.-S.; Smith, A. B., III. Org. Lett. 2005, 7, 3569-3572. (b) Andrus, M. B.; Li, W.; Keyes, R. F. J. Org. Chem. 1997, 62, 5542-5549.

(7) (a) Prior, W. A.; Giamalva, D.; Church, D. F. J. Am. Chem. Soc. 1983, 105, 6858-6861. (b) Paterson, I.; Paquet, T.; Dalby, S. M. Org. Lett. 2011, 13, 4398-4401.

(8) Zambrana, J.; Romea, P.; Urpí, F.; Lujan, C. J. Org. Chem. 2011, $76,8575-8587$. 
previous ozonolysis step. At this stage, a $\mathrm{SmI}_{2}$-induced intramolecular Reformatsky reaction, proceeding under neutral conditions, ${ }^{9}$ followed by dehydration, provided a remarkably efficient entry to the $\alpha, \beta$-unsaturated $\delta$-lactone $13(79 \%)$. Subsequent chemo- and diastereoselective syndihydroxylation afforded $\delta$-lactone $\mathbf{1 4}$ in quantitative yield and excellent diastereoselectivity $(\mathrm{dr}>95: 5)($ Scheme 3$) .{ }^{10}$

Scheme 3. Synthesis of the C16-C25 Subunit $\mathbf{1 5}$

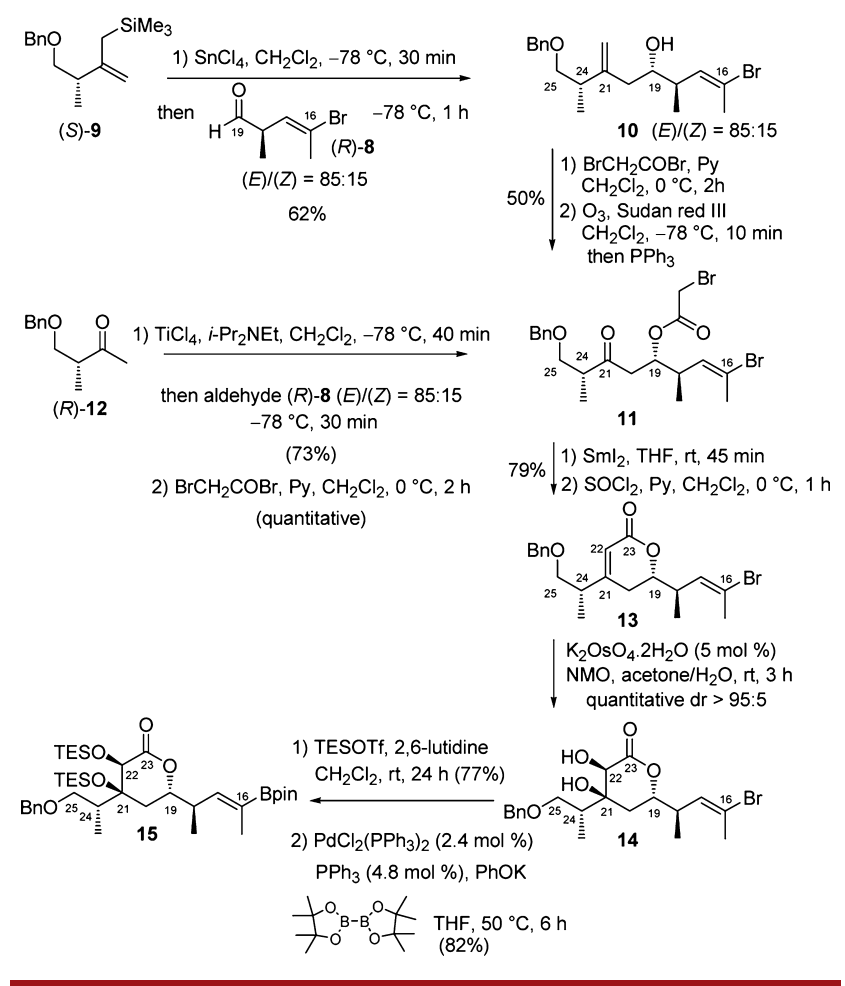

Protection of the 1,2-diol as a bis-triethylsilyl ether $(77 \%)^{11}$ followed by a palladium-catalyzed borylation of the trisubstituted alkenyl bromide $\mathbf{1 4}$ with bis(pinacolato)diboron $^{12}$ eventually delivered, in $82 \%$ yield, the trisubstituted $(E)$-alkenylboronate $\mathbf{1 5}$ armed for further functionalization at both terminii.

The preparation of the $\mathrm{C} 16-\mathrm{C} 25$ fragment has been achieved in 7 steps from methyl ketone 12, implying a total of 10 steps from the $(R)$-Roche ester (24\% overall yield).

The synthesis of the $\mathrm{C} 7-\mathrm{C} 15$ subunit $\mathrm{C}$ was then undertaken from Weinreb amide 16. We have previously described the preparation of this latter compound from the $(S)$ Roche ester by iterative aldol reactions, during the synthesis of model compounds for the assignment of the relative configuration of the $\mathrm{C} 8-\mathrm{C} 13$ subunit. $^{3}$ Addition of the

(9) (a) Molander, G. A.; Etter, J. B. J. Am. Chem. Soc. 1987, 109, 6556-6558. (b) Molander, G. A.; Brown, G. A.; Storch de Gracia, I. J. Org. Chem. 2002, 67, 3459-3463.

(10) As for lactone $\mathbf{5}^{4}$ the relative configuration of lactone $\mathbf{1 4}$ was confirmed by NOESY (see Supporting Information).

(11) At this stage, the benzyl ether at $\mathrm{C} 25$ can be cleaved in high yield in the presence of DDQ $\left(\mathrm{CH}_{2} \mathrm{Cl}_{2}\right.$, reflux) which may be useful to achieve coupling with the $\mathrm{C} 26-\mathrm{C} 46$ subunit.

(12) Matsumura, D.; Takarabe, T.; Toda, T.; Hayamizu, T.; Sawamura, K.; Takao, K.-i.; Tadano, K.-i. Tetrahedron 2011, 67, 6730-6745. organolithium generated from the $(E)$-alkenyl iodide $17^{13}$ to Weinreb amide $\mathbf{1 6}$ afforded $\beta$-silylenone $\mathbf{1 8}$ in almost quantitative yield $(99 \%)$. Cleavage of the TMS ether at $\mathrm{C} 11$ led to a $\beta$-hydroxyketone which underwent diastereoselective reduction with $\mathrm{Zn}\left(\mathrm{BH}_{4}\right)_{2}(\mathrm{dr}=90: 10)$ to afford the $s y n-1,3$-diol 19 (87\%) (Scheme 4). ${ }^{14}$

Scheme 4. Synthesis of the C7-C16 Subunit 20

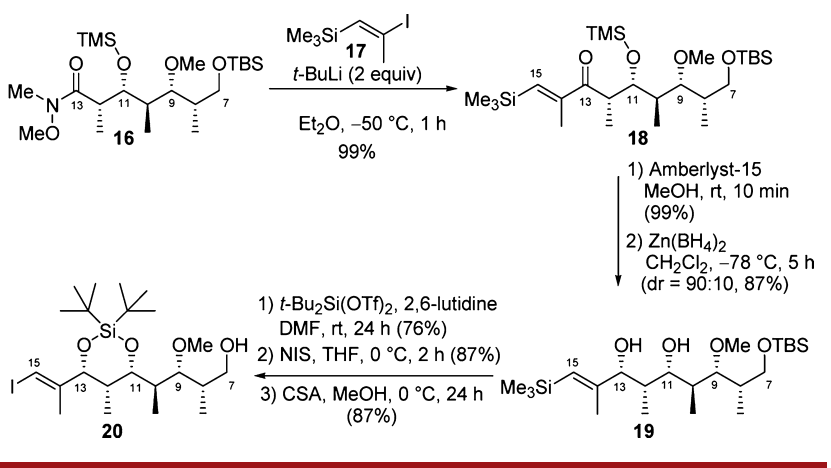

The choice of the protecting groups for 1,3-diol 19 was crucial. When 19 was protected as di-TES ether, subsequent iododesilylation under standard conditions did not readily proceed. Use of a cyclic ketal proved to be essential to perform this reaction. As the acidic removal of acetonide at the end of the synthesis could be problematic, ${ }^{15}$ it became apparent that the most successful route would involve protection of $\mathbf{1 9}$ as a di-(tert-butyl)-silylene ketal, with final deprotection with fluoride sources under mild conditions. ${ }^{16,17}$ Thereby, after protection of $\mathbf{1 9}$ as a cyclic silylene ketal, iododesilylation, and chemoselective cleavage of the TBS ether at C7, the (E)-alkenyl iodide 20 corresponding to the $\mathrm{C} 7-\mathrm{C} 16$ subunit of hemicalide was obtained (6 steps from Weinreb amide 16, 49\% overall yield) (Scheme 4).

As the preparation of phosphonate 21, corresponding to the $\mathrm{C} 1-\mathrm{C} 6$ subunit $\mathbf{D}$, has been previously achieved from 2-trimethylsilylethyl sorbate using a chemoselective cross-metathesis with allyl bromide followed by an Arbuzov reaction, ${ }^{3}$ the assembly of the three subunits $\mathbf{B}, \mathbf{C}$, and $\mathbf{D}$ was investigated.

The primary alcohol 20 was oxidized with Dess-Martin periodinane (DMP), and aldehyde $\mathbf{2 1}$ was engaged in an $\mathrm{H}-\mathrm{W}-\mathrm{E}$ olefination with the lithium salt of phosphonate 22 (Scheme 5). The resulting (E,E,E)-triene $\mathbf{2 3}$ was obtained

(13) Nicolaou, K. C.; Piscopio, A. D.; Bertinato, P.; Chakraborty, T. K.; Minowa, N.; Koide, K. Chem.-Eur. J. 1995, 1, 318-333.

(14) The relative configuration of the $\mathrm{C} 13$ stereocenter was confirmed by examination of the ${ }^{13} \mathrm{C}$ NMR spectrum of 19 . A characteristic low ${ }^{13} \mathrm{C}$ NMR chemical shift $(\delta=4.1 \mathrm{ppm})$ was noticed for the sole $\mathrm{C} 12$ methyl group: this value is consistent with a syn-syn stereotriad (see Supporting Information). (a) Hoffmann, R. W.; Weidmann, U. Chem. Ber. 1985, 118, 3980-3992. (b) See ref 3.

(15) Bock, M.; Dehn, R.; Kirschning, A. Angew. Chem., Int. Ed. 2008, 47, 9134-9137.

(16) Colobert, F.; Choppin, S.; Ferreiro-Mederos, L.; Obringer, M.; Luengo Arratta, S.; Urbano, A.; Carreno, M. C. Org. Lett. 2007, 9, 4451-4454.

(17) Baker, T. M.; Edmonds, D. J.; Hamilton, D.; O’Brien, C. J.; Procter, D. J. Angew. Chem., Int. Ed. 2008, 47, 5631-5633. 
in excellent yield (92\%), and the alkenyl iodide at C15 underwent a remarkably smooth Suzuki-Miyaura coupling with the previously synthesized alkenyl pinacol boronate $15(\mathrm{C} 16-\mathrm{C} 25$ subunit $)$, catalyzed by $\mathrm{Pd}\left(\mathrm{PPh}_{3}\right)_{4}$ and in the presence of aqueous TlOEt as the base. ${ }^{18}$ Under these conditions, compound $\mathbf{2 4}$ possessing the desired trisubstituted $(E, E)-\mathrm{C} 14-\mathrm{C} 17$ diene of hemicalide was isolated in very high yield (97\%) (Scheme 5).

Scheme 5. Synthesis of the C1-C25 Subunit of Hemicalide 25

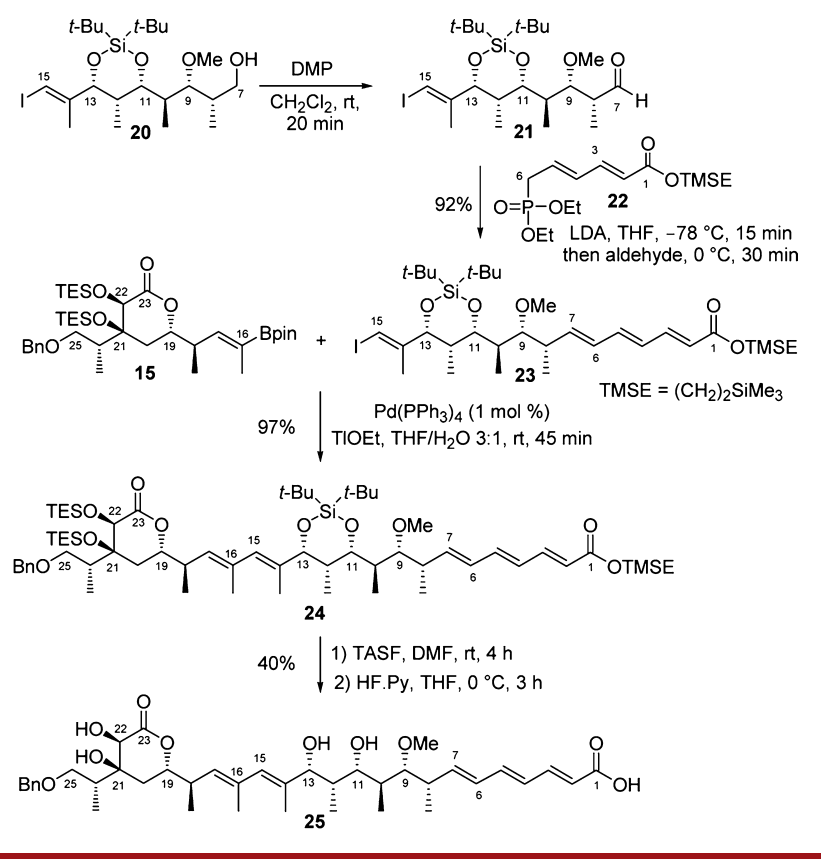

Based on our selection of silyl protecting groups, the final deprotection could be accomplished in two steps using tris(dimethylamino)sulfonium difluoro trimethyl silicate (TASF) (DMF, rt) to cleave the TES ethers and the 2-trimethylsilyl ester first, and then buffered HF.Py was

(18) (a) Miyaura, N.; Yamada, K.; Suginome, H.; Suzuki, A. J. Am. Chem. Soc. 1985, 107, 972-980. (b) Ghidu, V. P.; Wang, J.; Wu, B.; Liu, Q.; Jacobs, A.; Marnett, L. J.; Sulikowski, G. A. J. Org. Chem. 2008, 73, 4949-4955. (c) Wu, B.; Liu, Q.; Sulikowski, G. A. Angew. Chem., Int. Ed. 2004, 43, 6673-6675. (d) Francais, A.; Leyva, A.; Etxebarria-Jardi, G.; Ley, S. V. Org. Lett. 2010, 12, 340-343. utilized to deprotect the 1,3-diol at C11,C13 (Scheme 5). The synthesis of compound $\mathbf{2 5}$ corresponding to one putative stereoisomer of the $\mathrm{C} 1-\mathrm{C} 25$ fragment of hemicalide was thus successfully completed.

It was interesting to compare the NMR spectroscopic data of hemicalide with those of compound 25 which should constitute one of the two possible diastereomers of the $\mathrm{C} 1-\mathrm{C} 25$ subunit based on our previous stereochemical assignment studies. ${ }^{3,4,19}$ Since the natural product was isolated as a carboxylate salt, significant chemical shift differences were observed in the trienic region (for $\mathrm{H} 3$ and carbons $\mathrm{C} 1-\mathrm{C} 7$ ), as previously noted. ${ }^{3}$ For the $\mathrm{C} 8-\mathrm{C} 24$ segment, the ${ }^{1} \mathrm{H}$ and ${ }^{13} \mathrm{C} \mathrm{NMR}$ chemical shifts of compound $\mathbf{2 5}$ were in good agreement with those of hemicalide $(|\Delta \delta| \leq 0.12 \mathrm{ppm}$ and $|\Delta \delta| \leq 1.2 \mathrm{ppm}$, respectively). In particular, differences were insignificant in the $\mathrm{C} 8-\mathrm{C} 17$ region, but the presence of a benzyl ether at $\mathrm{C} 25$ in compound $\mathbf{2 5}$ does not obviously allow for a more relevant comparison with the natural product at this stage.

In conclusion, we have developed a highly convergent approach to one possible diastereomer of the $\mathrm{C} 1-\mathrm{C} 25$ subunit of hemicalide. The strategy relies on formation of the $\mathrm{C} 6-\mathrm{C} 7$ olefin by an $\mathrm{H}-\mathrm{W}-\mathrm{E}$ olefination and creation of the C15-C16 bond by a Suzuki-Miyaura coupling. Our results demonstrate the remarkable efficiency of the Suzuki-Miyaura coupling for construction of the C14-C17 conjugated diene of hemicalide with highly functionalized partners and strongly encourage its use as a possible endgame in the synthesis of hemicalide (or stereoisomers), a program currently underway in our laboratories.

Acknowledgment. We thank Pierre Fabre Laboratories and the CNRS for a doctoral fellowship for E.F. and the CNRS for postdoctoral fellowships for G.S. and S.S.

Supporting Information Available. Experimental procedures and full analyses of ${ }^{13} \mathrm{C}$ and ${ }^{1} \mathrm{H}$ NMR spectra for all compounds. This material is available free of charge via the Internet at http://pubs.acs.org.

(19) Tables of comparison are provided in the Supporting Information.

The authors declare no competing financial interest. 